\title{
Researcher identities and practices inside centres of excellence
}

\author{
Siri Brorstad Borlaug ${ }^{1^{*}}$ (D) and Magnus Gulbrandsen ${ }^{2}$
}

\author{
* Correspondence: \\ siri.borlaug@nifu.no \\ ${ }^{1}$ Nordic Institute for Studies in \\ Innovation, Research and Education \\ (NIFU), Oslo, Norway \\ Full list of author information is \\ available at the end of the article
}

\begin{abstract}
Many science support mechanisms aim to combine excellent research with explicit expectations of societal impact. Temporary research centres such as 'Centres of Excellence' and 'Centre of Excellence in Research and Innovation' have become widespread. These centres are expected to produce research that creates future economic benefits and contributes to solving society's challenges, but little is known about the researchers that inhabit such centres. In this paper, we ask how and to what extent centres affect individual researchers' identity and scientific practice. Based on interviews with 33 researchers affiliated with 8 centres in Sweden and Norway, and on institutional logics as the analytical framework, we find 4 broad types of identities with corresponding practices. The extent to which individuals experience tensions depend upon the compatibility and centrality of the two institutional logics of excellence and innovation within the centre context. Engagement in innovation seems unproblematic and common in research-oriented centres where the centrality of the innovation logic is low, while individuals in centres devoted to both science and innovation in emerging fields of research or with weak social ties to their partners more frequently expressed tension and dissatisfaction.
\end{abstract}

Keywords: Research centres, Excellence, Innovation, Institutional logics, Science policy

\section{摘要}

许多科学支持机制目的在于将卓越的研究与对社会影响的明确期望结合起 来。像“卓越中心”和“卓越研究与创新中心”这样的临时研究中心已经变得日益普 遍。预计这些中心将开展研究,创造未来的经济效益,且有助于解决社会的挑 战，但是，我们对处于这些中心的研究人员却知之甚少。在本文中，我们质问这些 中心如何以及在多大程度上影响个体研究人员的身份和科学实践。根据对瑞典 和挪威八个中心的33名研究人员的访谈,将机构逻辑作为分析框架,我们发现了四 种广泛类型的身份和相应的实践。个人经历紧张的程度取决于在中心内部卓越 和创新两种制度逻辑的兼容性和中心性。在创新逻辑的中心性较低的研究导向 型中心,参与创新似乎是没问题和普遍的,而在新兴研究领域或与其合作伙伴之间 的社会联系弱的中心,致力于科学和创新的个人更频繁地表现出紧张和不满。 


\section{Résumé}

Plusieurs mécanismes d'appui à la science visent à combiner une recherche excellente à l'attente d'un impact sociétal. Les centres de recherche temporaires comme les "Centres d'excellence" et "Centres d'excellence en recherche et innovation" sont devenus légion. Ces centres doivent mener des recherches qui devront produire des bénéfices économiques et contribuer à relever les défis qui se posent à la société; cependant, on connaît très peu sur les chercheurs qui habitent ces centres. Dans cet article, nous répondons à la question "Comment et dans quelle mesure les centres affectent-ils l'identité et les pratiques scientifiques des chercheurs ?". Sur la base d'interviews avec 33 chercheurs affiliés à huit centres en Suède et au Norvège, et sur la base de la logique institutionnelle comme cadre analytique, nous avons identifié quatre grand types d'identités avec des pratiques correspondantes. Le degré de tensions vécues par les individus dépend de la compatibilité et de la centralité des deux logiques institutionnelles d'excellence et d'innovation dans le contexte du centre. L'engagement à l'innovation ne semble pas problématique et est commun aux centres axés sur la recherche où la centralité de la logique de l'innovation est faible, alors que les chercheurs des centres dédiés à la fois à la science et à l'innovation dans les domaines émergents de recherche ayant des liens sociaux faibles avec les partenaires expriment plus fréquemment des tensions et du mécontentement.

\section{Resumo}

Vários mecanismos de suporte à ciência almejam combinar excelência em pesquisa e expectativas claras de impacto social. Centros temporários de pesquisa tais como "Centres of Excellence" e "Centre of Excellence in Research and Innovation" tornaramse difundidos. Espera-se de tais centros a produção de pesquisas que criem benefícios econômicos futuros e que contribuam para a solução de desafios da sociedade, entretanto, pouco se sabe a respeito dos pesquisadores que ocupam tais centros. Neste artigo, questionamos como e quais centros de extensão afetam a identidade individual de pesquisadores e suas práticas científicas. Baseado em entrevistas com 33 pesquisadores afiliados a 8 centros na Suécia e Noruega e em lógicas institucionais como estrutura analítica, encontram-se 4 grandes tipos de identidade com práticas correspondentes. A dimensão de cada experiência individual depende da compatibilidade e centralidade das duas lógicas institucionais de excelência e inovação dentro do contexto do respectivo centro. Compromisso com a inovação soa não problemático e comum em centros de pesquisas orientadas onde a centralidade de inovação lógica é baixa, enquanto pesquisas individuais em centros voltados à ciência e à inovação, em áreas emergentes de pesquisa ou com laços sociais fracos expressaram, mais frequentemente, tensão e insatisfação.

\section{Аннотация}

Большинство механизмов поддержки науки ориентированы на комбинацию успешных исследований с эксплицитным ожиданием социального эффекта. Исследовательские центры, такие как "Центр передовых технологий" и "Центр Совершенствования исследований и инноваций", появляются повсеместно. Считается, что в таких центрах проводятся исследования, способствующие созданию положительных экономических эффектов в будущем и разрешению социально-значимых вопросов; при этом, мало внимания уделяется самим ученым, работающим в данных центрах. В данной статье мы задались вопросом о (Continued on next page) 
(Continued from previous page)

том, как и в какой мере эти центры оказывают влияние на личностные качества

исследователей и их научные достижения. Мы провели интервью с 33

исследователями, работающими в восьми различных центрах в Швеции и Норвегии, проанализировав которые мы выявили четыре типа сообществ с различными характеристиками. Степень вовлеченности работников зависит от совместимости и центральности двух институциональных моделей управления передовыми технологиями и инновациями в рамках самого центра. Вовлечение в инновации считается обычной практикой в исследовательских центрах, где центральность инновационной модели низка, в то время как сами работники в центрах занимаются исследованиями и инновациями в смежных областях науки или имеют слабые социальные связи со своими партнерами, что часто выражающиеся с виде давления или неудовлетворенности.

\section{Resumen}

Existe un creciente interés en los gestores de políticas públicas de promover, a la vez, la excelencia y el impacto social de la investigación científica. Como consecuencia, centros de excelencia se han multiplicado. Se espera que estos centros produzcan investigaciones con beneficios económicos y que contribuyan a resolver desafíos sociales, pero se sabe poco acerca de los investigadores empleados en estos centros. En este documento, preguntamos en qué medida los centros afectan la identidad y las prácticas científicas de sus investigadores. Sobre la base de entrevistas con 33 investigadores afiliados a ocho centros en Suecia y Noruega, encontramos cuatro tipos generales de identidades que corresponden a prácticas específicas. Cuando los centros no reconcilian las lógicas de excelencia e innovación, los investigadores internalizan esa tensión. Los centros que enfatizan la excelencia sobre la innovación, irónicamente, tienen menos dificultad en conseguir que sus investigadores se involucren en tareas de innovación. Por el contrario, los investigadores de centros que enfatizan equivalencia entre excelencia e innovación, reportan estar generalmente estresados y descontentos. Esto es particularmente cierto en centros con vínculos sociales débiles.

\section{Multilingual abstract}

Please see Additional file 1 for translation of the abstract into Arabic.

\section{Introduction}

How and why do university researchers change their practices, and what are the agents and preconditions of change? The expansion of innovation activities within universities from the 1980s contributed to changed practices at least among some academics (Etzkowitz 1998). The latter decades policymakers have sought to make innovation more widespread by supporting 'triple helix' relationships, i.e. co-evolutionary processes involving universities, firms and policymakers (Etzkowitz and Leydesdorff 2000). The hope is that new funding and collaboration mechanisms may act as agents of change in research and innovation systems, but there is limited systematic evidence about how such mechanisms affect individual academics.

In this paper, we analyse research-funding mechanisms' influence on how researchers work and talk about their own role, i.e. their research practices and identity. We look in particular at two different funding schemes: Centres of Excellence supporting 
academic research and collaboration, and Centres of Excellence in Research and Innovation, which target triple helix collaboration across academic, public and private sectors. Both schemes provide substantial, flexible and long-term funding. Innovation may be desired in both types of centres but is only formally required in one of them.

We address two issues that have received limited attention in the literature (Gläser and Laudel 2016). The first concerns the effect of funding mechanisms on individual researchers (Nedeva et al. 2012). It is likely that the effect depends, for example, on the match between the characteristics of funding instruments, professional values and norms (Dooris and Fairweather 1992; Leisyte and Enders 2011) and wider societal conditions such as the funding of universities (Whitley 2003). The second issue is the interplay between the goals of excellence and innovation (Hessels and van Lente 2011), including the institutional and organisational conditions under which such research is conducted (Heinze et al. 2009; Jain et al. 2009).

We use the framework of institutional logics (Friedland and Alford 1991; Thornton et al. 2012) to analyse how the norms and values built into the logics of excellence and innovation influence individual researchers affiliated with these two different centres. The logics of excellence and innovation may sometimes be in conflict but also overlap depending on their degree of compatibility and centrality in each specific situation (Besharov and Smith 2014), resulting in different degrees of synergy, negotiations and tensions. This offers an opportunity to study temporary research centres as agents of change: how researchers relate to and identify with the logics associated with the centres (Meyer and Hammerschmid 2006), also in order to better understand the logics associated with triple helix relations.

Our contribution is an analysis of 33 researchers in 8 centres in 2 countries and in different disciplines, which concludes with 4 idealised categories. These reflect how the centre schemes influence how researchers relate to the institutional logics of excellence and innovation in their research. Tensions dominate only one of the categories, most often found in contexts characterised by immature university-industry relations, new research fields and dependency on many sources of funding. For most researchers, however, affiliation with a centre involving excellence either creates legitimacy for their pre-established choice of researcher identity or creates a protected space for experimentation with new activities. Our analysis indicates that funding mechanisms aiming to be agents of change of academic behaviour may need specific preconditions in order to be effective.

The paper is organised as follows: First, we present institutional logics and discuss issues related to the concepts of excellence and innovation and questions of identity. The next section contains methodology and data, followed by our analysis of different aspects of identity and practice. The last sections analyse four ideal type identities emerging from our empirical data, ending with conclusions and suggestions for policy and for further research.

\section{The institutional logics of excellence and innovation}

An institutional logic is, according to Friedland and Alford (1991, p. 248) 'a set of material practices and symbolic constructs which constitutes its organising principles and which is available to organisations and individuals to elaborate'. Institutional logics thus contribute to identity (Rao et al. 2003), legitimacy and a sense of order for the actors 
(Thornton et al. 2012). Logics provide guidelines for actors on how to interpret and function in social situations (Greenwwod et al. 2011).

Organisations often face multiple logics that may be compatible or incompatible (Greenwwod et al. 2011; Kraatz and Block 2008). For instance, universities may be influenced by the institutional logics of the market, the public sector and that of their diverse academic professions-with their cognitive and normative orders. The plurality of logics can generate challenges and tensions for the organisation and the individuals exposed to them. For our purpose, they also represent central preconditions for changing individual practices.

The degree of tension depends on the compatibility between the logics and on their centrality (Besharov and Smith 2014). Centrality is the degree to which multiple logics are treated as equally valid and relevant to organisational functioning (ibid., p. 369). If one single logic guides core operations and the others are manifested in peripheral activities, the centrality dimension is low. Likewise, if multiple logics are instantiated in core activities, centrality is high. This implies that if both the degree of centrality and compatibility is low, there will be a moderate conflict between the logics, and if the degree of centrality is high and the compatibility is low, there may be an extensive conflict between the logics.

We contend that excellence and innovation can be characterised as two separate institutional logics at universities, as they are characterised by distinctive goals, identities and practices. Excellence is associated with forefront research and scientific reputation evaluated by discipline-specific markers (cf. Luukkonen et al. 2006; Lamont 2009), and relates to a traditional form of basic research (Gulbrandsen and Kyvik 2010; Hollingsworth 2008). It is intimately tied to ideas like academic freedom and scientific curiosity (Calvert 2004), science as a public good (Slaughter and Rhoades 2004) and scientific publications as the main output (Leisyte and Hosch-Dayican 2016). Innovation, on the other hand, is often associated with triple helix relations, research of an applied character and linked to concepts such as knowledge and technology transfer (Geuna and Muscio 2009), and therefore often involves collaboration with for-profit partners outside academia.

\section{Centres and researchers' identities and practices}

In the past decades, research-funding agencies have increasingly supported research centres with the goal of excellence and/or innovation (Orr et al. 2011). Centres are new units or long-term projects that often span institutional and organisational boundaries with participants from different disciplines and organisations such as universities, industry and public agencies (Boardman and Bozeman 2007; Boardman and Gray 2010). They may also be established by the universities and are part of a wider trend of supporting change in universities through organisational changes (Etzkowitz and Peters 1991; Etzkowitz and Kemelgor 1998). This paper discusses centres as a policy instrument for impacting the practices of university researchers,

Centres are found in mature and emerging research areas. Following institutional theory (cf. Greenwwod et al. 2011), emerging or young areas are often characterised by a high degree of incompatibility or conflict between different institutional logics. Mature areas, on the other hand, are more likely to have stable priorities and enjoy legitimacy of practices and identities. The tendency to engage in cross-sector collaboration is most 
frequent in technological disciplines (Perkmann et al. 2011; Gulbrandsen and Smeby 2005). One reason is likely that it is easier to find research problems of mutual interest in some disciplines than in others and that disciplines vary in their norms and values (Merton 1973; Dooris and Fairweather 1992; Whitley 2000). We may assume that researchers in disciplines already familiar with industry collaboration will experience less conflict between the logics (Hessels and van Lente 2011).

The concept of identity is important in order to understand how individuals respond; it forms a central link between the behaviour of the individual and institutional logics (Lok 2010; Friedland and Alford 1991). The notion of identity has received considerable attention in organisational studies (Alvesson et al. 2008; Glynn 2008). Identity can be understood as matters encountered by individuals, i.e. social beings embedded in organisational contexts, referring to subjective meanings and experience (Alvesson et al. 2008). Social identity 'refers to an individual's perception of him or herself as a member of a group, particularly in terms of value and emotional attachment' (Alvesson et al. 2008, p. 10).

Previous research on the role and identity of academics has highlighted the experiences of entrepreneurial researchers in pursuing activities outside of the realm of academia as they cross boundaries and break with social expectations. Atkinson-Grosjean (2006) identified two main researcher identities in a government sponsored programme aimed at enhancing innovation and excellence in life science: 'settlers' and 'merchants'. The settlers are researchers that conform to the traditional conception of an academic-preoccupied with autonomous and basic research. Merchants, contrarily, strive to unite the world of science with industry. Atkinson-Grosjean found that having a position as a 'settler' in academia is relatively unproblematic and tension free, whilst a 'merchant' position is a common source of conflict and resentment. The government programme made the transitions between these two positions more respectable.

Owen-Smith and Powell (2002) studied life-science faculty responses to a changing institutional environment with increased emphasis on research commercialisation. They found four identities, first a distinction between 'old school' researchers, who claim the academy is fundamentally different from industry and threatened by commercialisation, and 'new school' with the opposite position. They also distinguished between two hybrid positions: the 'reluctant entrepreneur' and the 'engaged traditionalist'. Their argument is that there is a complex array of positions that faculty can take in response to changes.

These studies highlight the heterogeneity of researcher activities and identities and provide fruitful starting points for a more detailed investigation of how the logics of excellence and innovation play out within an important new funding mechanism. We believe that the degree of compatibility and centrality of the institutional logics of excellence and innovation, and researchers' identification with them, can be readily observed in centre funding mechanisms. These are focused on research rather than teaching, and many of them formally incorporate multiple logics. We will look at practical and performative aspects of identity: how do researchers characterise their own role and activities, how do they select problems and how do they exchange knowledge with external partners?

\section{Context and methodology}

We have studied researchers affiliated with two types of centres of excellence in Sweden and Norway through a qualitative interview-based approach. This allows us to understand how funding schemes and their goals may affect researcher identity and 
practices, taking three important preconditions into account: the centres themselves (the funding mechanisms), the wider national system and disciplinary characteristics.

Centres of Excellence (CoE) and Centres of Excellence in Research and Innovation (CoERI) constitute two distinct ways of organising within the two institutional logics. They represent opportunities to compare how researchers draw upon the repertoires of excellence and innovation. Similarities between the two funding schemes include rather generous and long-term funding, temporality (limited to 8 to 10 years in our cases) and that members retain a main affiliation with another unit. The centre types differ, however, in their formal/informal collaboration with actors outside of the university. Whereas CoEs generally involve academic researchers, CoERIs are obliged to collaborate with actors from industry and/or public agencies. Still, universities most often host both types of centres, meaning they are legitimated first in an academic environment.

We have chosen to study centres in Norway and Sweden as these countries differ in their research funding systems and intellectual property legislation. Norway has one research funding agency and a fairly high level of block funding to universities, while Swedish researchers are subject to a more competitive research funding system with nine government research funding agencies. Swedish researchers therefore often fund their research from multiple sources. Sweden has furthermore decided to continue the professorial ownership of the rights to commercialise research results, while Norway gave this right to the higher education institutions in 2003. There is limited evidence on whether this has had any effect on researchers in technology transfer-oriented centres. Sweden introduced the CoERI scheme in 1995 and Norway in 2005, ${ }^{1}$ while Norway launched the CoE scheme in 2002, followed by Sweden in $2005 .^{2}$

We selected four CoERIs and four CoEs, two of each in each country from disciplines in mature scientific fields and in emerging ones. The expectation was that mature scientific fields had close contact and collaboration with external partners prior to the centre formation. Table 1 provides an overview of the different centres in our empirical study, and the character of their relations with non-academic actors.

We chose centres that had been operative for at least 2 years to ensure that respondents had ample experiences with being a 'centre researcher'. All centres are located at one university in Sweden and one in Norway. To avoid introducing yet another analytical dimension, we chose two very similar universities-broad, large

Table 1 Overview of the centres hosting our respondents

\begin{tabular}{|c|c|c|c|c|}
\hline Centre & $\begin{array}{l}\text { Established } \\
\text { year }\end{array}$ & $\begin{array}{l}\text { Level of external } \\
\text { relations }\end{array}$ & $\begin{array}{l}\text { New / long-term } \\
\text { relations }\end{array}$ & $\begin{array}{l}\text { Emerging/ } \\
\text { Mature field }\end{array}$ \\
\hline \multicolumn{5}{|l|}{ Centre of Excellence } \\
\hline Humanities & 2007 & Individual & Fluctuating* $^{*}$ & Mature \\
\hline Natural sciences & 2003 & Centre/individual & Long & Emerging \\
\hline Social sciences & 2006 & Individual & Long & Mature \\
\hline Medicine & 2006 & Individual & Fluctuating & Mature \\
\hline \multicolumn{5}{|c|}{$\begin{array}{l}\text { Centre of Excellence in Research and } \\
\text { Innovation }\end{array}$} \\
\hline Natural sciences & 2006 & Centre & Long & Mature \\
\hline Mathematics & 2006 & Centre & New and long & Mature \\
\hline Medicine and natural science & 2007 & Centre & New & Emerging \\
\hline Engineering & 2007 & Centre & New & Emerging \\
\hline
\end{tabular}

${ }^{a}$ Varies, the relations are not permanent 
and old research universities. We interviewed 3-5 researchers in each centre, in total 33 in the period April 2009 to February 2010. This includes centre leaders and other researchers in key or project leader positions. Except the centre leader whose position is normally financed by the scheme, they all have formal employment in other departments but are affiliated with the (temporary) centre. We used a semi-structured interview guide that included categories such as definition of own research, organisation of collaboration and knowledge and technology transfer. The interviews lasted from one to one and a half hours. Interview data was recorded and transcribed. The data are some years old, but the schemes were neither new in the system when the study was undertaken nor has any large changes (in the schemes or in national policies) occurred the past 8 years. We see the tensions uncovered in the analysis as still highly relevant, also as countries all over the world strengthen similar funding schemes.

We developed the characteristics of the institutional logics of excellence and innovation based on the literature review and themes that seemed recurrent in the interviews which specified the differences between the logics. Table 2 gives an overview of the categories.

We further selected categories for analysis which included situations where researchers provided statements about their academic identities and practices. In the analysis, we weighted researchers' description and used their language as interpretations for confining to one or both institutional logics. We looked for cues such as how they talked about their research, how they characterised knowledge and technology transfer, and how they managed collaboration. We looked for within group similarities coupled with intergroup differences (Eisenhardt 1989). To develop the identity categories, we followed the suggestions of Rao et al. (2003) and Meyer and Hammerschmid (2006) and did not use binary identity codes but allowed for the development of potential hybrid forms. Limitations to the study include the many differences in disciplinary affiliation and the part-time association with the centres. We have tried to deal with this by elucidating some of the values and beliefs of the disciplines (Dooris and Fairweather 1992) and by focusing on the actual work in the centres.

\section{Results}

The aim of the paper is to analyse the schemes Centres of Excellence (CoEs) and Centres of Excellence in Research and Innovation (CoERIs) as agents of change. This means to analyse how they might reinforce or generate conflicts for the affiliated researchers and how individuals negotiate between and draw upon the institutional logics of excellence

Table 2 First coding: characteristics of the institutional logics of excellence and innovation

\begin{tabular}{l|ll}
\hline Characteristics & Logics of excellence & Logics of innovation \\
\hline Goal & Forefront research & $\begin{array}{l}\text { New/improved technology, } \\
\text { products, processes, services }\end{array}$ \\
Source of identity & $\begin{array}{l}\text { Applied research } \\
\text { External collaboration }\end{array}$ \\
Sutonomy & $\begin{array}{l}\text { Industry, society, research } \\
\text { community }\end{array}$ \\
Core practices & Research community & $\begin{array}{l}\text { Publication, technology and } \\
\text { knowledge transfer }\end{array}$ \\
\hline
\end{tabular}


and innovation. We start by analysing the perceptions of and goals of the funding mechanisms, followed by problem choice and research practice, and technology transfer.

\section{Perceptions of the research in the centres and the aims of the funding mechanism}

The incompatibilities and degree of centrality between the different logics were highly visible in both types of centres when discussing their goals.

\section{Centres of excellence in research and innovation}

In the CoERIs, the informants' responses differed between countries. The two Norwegian centres were in mature and well-established fields. Most of the Norwegian researchers emphasised the basic orientation of their research: 'I have a typical basic researcher's head. (...) My role in the centre is to assure that the academic output holds high quality' (senior researcher, mathematics). Even though this informant was active in the centre's research, he distanced himself from its dual mandate. Instead, he emphasised the institutional logics of excellence through autonomy, long timeframes and publication in journals. A researcher in another centre indicated that the norms and values in academia are often incompatible with what counts in a centre with goals of innovation. Another member of the same centre confirmed: 'We do fundamental research at the university while our partners do the applied'. The division of labour in the research system sustained the traditional perception of university researchers' research activities.

However, the Norwegian CoERI centre leaders, whose network had been vital for the establishment of the centres, had more inclusive and instrumental perspectives on industry collaboration. These were typical boundary-spanning actors, who juggled the different roles with few problems, having a solid conviction of the quality of their own research. We thus see that within the same centre, there are multiple logics at work represented in the heterogeneous personnel that populate the centres (Kraatz and Block 2008; Powell and Colyvas 2008).

The emphasis on basic research was much less evident in Sweden, and we see two important explanations. First, one of the centres represented a relatively new academic field created at the intersection of industry and the university and accustomed to applied work, while the other Swedish CoERI was within a highly applied speciality. Second, several of the Swedish researchers claimed that the strong applied dimension in the centres was a product of the funding system. One stated: 'It is difficult to get money for basic research now. It is easier to obtain funding when industry is involved.' Some of the centres in this study had difficulties finding funding outside of the council that manages the CoERI scheme.

The applied dimension of the CoERI combined with the quest for research excellence generated tensions: 'This is a $\mathrm{CoE}$ expected to deliver high quality scientific research but at the same time include the innovation component, which is extremely challenging' (Centre leader, Norway). The challenge lay in motivating and stimulating the university researchers to participate in innovation. Encouragement and resources were not always enough, and some informants told of some cases of researchers resigning from CoERIs due to the lack of success in developing interesting research questions. Membership in such a centre is for some unattractive and not coherent with their researcher identity.

Several CoERI researchers emphasised the lack of recognition and acknowledgement in the wider researcher community and society for the CoERIs: 'Nobody says "it was 
really good of you to achieve centre status", I never hear that about our type of centre' (senior researcher, Sweden). Another CoERI member claimed that a CoE is more exclusive than a CoERI, because in the latter the participation threshold is lower: 'anybody can join'. Researchers in mature academic fields adhere to practices and norms of basic research, and it is difficult to get these involved in the centres, a Swedish CoERI representative argued. Such perceptions were shared in both countries.

\section{Centres of excellence}

In the CoEs, the majority of informants-as expected-emphasised the importance of basic research: 'What we do in the centre should be basic research. We do not take on contract research' (centre leader, Sweden). For researchers like this, excellence is synonymous with basic research, similar to findings of Gulbrandsen and Kyvik (2010). Several researchers, including the humanities and social science representatives, also underlined that research should in the end 'have relevance' and that they had an obligation to disseminate their results, thereby invoking a weak and traditional academic interpretation of the institutional logic of innovation.

Contact with public agencies and industry was frequent but often individual in character. Only one case, the CoE in natural science, saw several affiliates involved in a collaboration project organised at the centre level. These researchers emphasised the feedback value to their own research and their role in participating in knowledge disseminationexperiencing few tensions as boundary spanning actors (Youtie and Shapira 2008). The strong weight given to basic research in the CoE created legitimacy also for researchers that engaged in innovation. The researchers were already embedded in a logic of excellence and experienced a high degree of compatibility with the logic of innovation; the centrality and compatibility between the logics were both high. The financing mechanisms contributed to sustaining and reinforcing the normative identity of the researcher.

Researchers affiliated with the CoERIs confirmed this perception. They underlined that the CoEs were often perceived as the elite, and the credibility offered by a CoE affiliation is attractive for ambitious researchers regardless of professional profile. Unlike CoERIs, CoEs are not bound by a contractual agreement to work out joint research questions with representatives from other sectors, and they can therefore interact with industry on their own terms and conditions.

Table 3 Collaboration practices and problem choice

Degree of compatibility between the logics (can they easily be combined?)

\begin{tabular}{|c|c|c|c|}
\hline \multirow{3}{*}{$\begin{array}{l}\text { Degree of } \\
\text { centrality } \\
\text { between } \\
\text { the logics } \\
\text { (are they } \\
\text { both } \\
\text { needed in } \\
\text { the } \\
\text { centre?) }\end{array}$} & & High & Low \\
\hline & High & $\begin{array}{l}\text { CoERI: Expanding the } \\
\text { tradition } \\
\text { "We are a Centre of } \\
\text { Excellence plus } \\
\text { Innovation" }\end{array}$ & $\begin{array}{l}\text { CoERI: Respect us for who } \\
\text { we are } \\
\text { "I have a basic } \\
\text { researcher's head" }\end{array}$ \\
\hline & Low & $\begin{array}{l}\text { CoE: Good research is } \\
\text { useful } \\
\text { "I do basic and relevant } \\
\text { research" }\end{array}$ & $\begin{array}{l}\text { CoE: Not getting your } \\
\text { hands dirty } \\
\text { "What we do in the } \\
\text { centre should be basic } \\
\text { research" }\end{array}$ \\
\hline
\end{tabular}


In Table 3, we have categorised the answers into groups denoting how the informants coped with the logics. The matrix also takes into account the researchers affiliation with a CoE or a CoERI.

Both logics were present in both centre types, but with some variation depending on the perceived compatibility and centrality of the logics. All the informants in the CoE in natural science made statements that showed a high degree of compatibility between the logics, but the centrality of the logics was low (only one needed to reach the centre goal). The researchers exposed a rather tension-free attitude compared to their colleagues from social sciences who largely made statements that excellence and innovation are/should be separate (low compatibility), even though they themselves collaborated with public agencies. In the CoERIs, both logics were central, but we also observed different identifications with the logics. In centres where the compatibility was contested, there were tensions, while in centres where the compatibility was perceived as high, the researchers identified with both logics.

\section{Problem choice and research practice}

Incompatibilities between the logics became further evident when researchers described the processes of selecting topics and moving from research questions to collaborative practice.

\section{Centres of excellence in research and innovation}

Challenges arose in harmonising demands from academics and industry about which research to perform. One informant in a Norwegian centre claimed:

....if I go to these people and ask them: which problem would you like to have solved in 5 years? What would you like to have in 5 years? [...You] do not get an answer.

[...T] he industrial perspective is maybe a year.

Research is expected to have a long-term perspective, drive the research frontier and at the same time produce innovations in a shorter time span. Problems escalate when the collaborating partners are small and their need is immediate problem solving.

The selection of research questions also depends upon how the research is perceived, and several talked about different degrees and relative perceptions: 'If you ask industry my research would be characterised as basic; I think of it as more applied' (researcher, Sweden). Different understandings of goals and how they should be attained can often create difficulties in achieving consensual decisions.

The logics of excellence and innovation further revealed themselves in the practices of the researchers. Even though they invoked the language of innovation, many practices contradicted the innovation logic (cf. Lok 2010). The centres were research-driven, and the centre leader and the majority of project leaders came from academia. Industry had more or less the role of a contractor and/or simply a recipient of research. Most of the interaction between industry and the academics was in the form of workshops or seminars where the researchers communicated their ideas and results to the audience, i.e. traditional academic communication/ dissemination patterns. The very format of the financing scheme seems to contribute to making the interaction converge on academic practises. All centres were 
monitored and evaluated during the centre period, and the main emphasis was on scientific outputs in terms of publications.

According to some of the informants, conservative academic practices could be a barrier to developing original research. One Swedish researcher asked: 'How can we move the research frontier? In academia we are [only] preoccupied with publishing in journals, participating at conferences and developing theories.' Another in a Norwegian centre stated:

'I train the scientists here to work in the innovation arena, which is new for them. Very very new. (...) I have to tell them every day: This is not the usual paper. It's something else. (...) I support this [centre] which is completely new for them and forces them to do innovation-based research [which would not happen without the centre].'

These informants work in CoERIs with mostly embryonic relations with industry partners, but one represents a mature academic field, which means that the logic of innovation may sometimes be incompatible in both mature and emerging academic fields. Another centre with a tradition for collaborating with industry experienced few tensions in practices related to the goal of innovation. Some of their research was based directly on the industrial partners' patents. For those who had well-established ties to their partners, the CoERI scheme represented an opportunity to formalise, concentrate and legitimise this type of research. Although the funding mechanism provided a home for the somewhat marginalised scientists (Gulbrandsen 2005) and eased the conflicts between the logics, the career path of academia posed perceived challenges if this type of work leads to fewer publications for younger researchers. CoERI leaders also mentioned convincing 'basic researchers' to devote time to the projects, but they tried to solve the challenge through negotiations and incentives like new equipment.

\section{Centres of excellence}

$\mathrm{CoE}$ researchers, on the other hand, did not experience challenges in developing joint research questions with industry. This was opportunity-driven, indicating synergies and overlap between the logics of excellence and innovation. The leader of a Norwegian centre said: 'We discuss research questions with industry and if they and we find something common and interesting we kill two birds with one stone.' This centre came to life due to a joint project between the university and a large firm, and one of the centre's core research questions emerged through this collaboration. Moreover, some of the centre's most cited research stemmed from a project initially developed by industry. The centre perceived and experienced a high degree of compatibility between the logics of excellence and innovation. One possible explanation is that the interactions were a result of the individuals' motivation and not because of conditions inherent in the financing scheme.

Many of the research practices found in CoEs are indistinguishable from normal scientific work, and since the CoE scheme does not require anything else, this does not imply a tension between the logics. Still, many of the interviewed researchers were motivated by practical concerns and engaged in collaboration with non-academic partners. As long as they could supervise graduate students and publish in prestigious journals, the CoE constituted a space with a large degree of freedom in experimenting with different research practices. 
Table 4 Collaboration practices and problem choice

Degree of compatibility between the logics

\begin{tabular}{|c|c|c|c|}
\hline & & High & Low \\
\hline & High & $\begin{array}{l}\text { CoERI: Integrated } \\
\text { collaboration } \\
\text { "The researchers work } \\
\text { on interesting research } \\
\text { problems generated by } \\
\text { the industrial partners" }\end{array}$ & $\begin{array}{l}\text { CoERI: Traditional } \\
\text { academic practices } \\
\text { "I continually have to } \\
\text { train the scientists to } \\
\text { work with innovation" }\end{array}$ \\
\hline $\begin{array}{l}\text { between } \\
\text { the logics }\end{array}$ & Low & $\begin{array}{l}\text { CoE: Mutual interest } \\
\text { "We kill two birds with } \\
\text { one stone" }\end{array}$ & $\begin{array}{l}\text { CoE: Keeping distance } \\
\text { "We decide upon our own } \\
\text { agenda" }\end{array}$ \\
\hline
\end{tabular}

In Table 4, we have summarised these findings. Informants who combined the logics in their characteristics of own research also did the same concerning practices. Tensions in the CoERI cases may be due to the newness of the collaboration with a low degree of institutionalised practices.

\section{Technology transfer}

Technology transfer is a goal of the CoERI scheme but a contested practice of the innovation logic (Borlaug and Jacob 2013; Jain et al. 2009). The attention to these practices varied in the centres.

Two of the CoERI leaders (one Norwegian, one Swedish) declared that patenting was not interesting and that they did not emphasise this activity: 'Our solutions are more incremental and it is the firms that commercialise them. As a leader I have not viewed patenting as important.' However, researchers in the same centre were involved in patenting processes or had established their own firm. The centres thus contained a dissonance between the technology transfer practices of its different members. This may indicate an incompatibility in the innovation logic related to how the centre is managed and which types of activities that are given priority.

One researcher in a Swedish centre experienced that his endeavours to patent and commercialise a technology was ignored by the management, resulting in some discontent. Others affiliated with the centre in natural science and medicine echoed this message.

All CoE leaders were indifferent towards intellectual property rights matters albeit some CoE researchers were engaged in technology transfer. The leaders emphasised that patenting may be too resource demanding in terms of time and money. Some researchers recognised the commercial potential of their own research but were reluctant to pursue it. One Swedish CoE researcher feared it would limit future opportunities for asking research questions, and the excellence logic was given priority in a decision-making situation. Several of the informants affiliated with a Norwegian CoE had experiences from patenting or establishing a firm, and for them these activities were compatible with the goal of the centre. 
Regardless of centre affiliation, the individual researchers seemed autonomous in their behaviour in terms of technology transfer practices. Even when this was a clear goal, the individual researchers and the centre leaders selectively adhered to this practice. A possible explanation for reluctance among the leaders is that they preferred to emphasise other innovation practices, since technology transfer and the property rights discussions that follow may conflict with the institutional logics of excellence.

\section{Discussion}

As seen, there are different perceptions of and identifications with the institutional logics of excellence and innovation among researchers affiliated with centres dedicated to excellence or to excellence and innovation. Four somewhat idealised identity categories can be created (Table 5) that reflect the alternative combinations of the logics which are at play within the different centres.

The categories are based on individual researchers' responses and are not a matrix about the centres, but rather connected to how the identity and practices of the researchers are moderated by the goals of the financing schemes. As such, the categories highlight how centres may act (nor not act) as agents of change in universities.

\section{The approved innovator}

This researcher is affiliated with a CoERI where both logics are central and have a high degree of compatibility, i.e. earlier successful combinations of academic practice and external utility. The CoERI scheme offers an opportunity to justify practices of innovation in an academic setting. Typical of these centres is mature relations between academic and non-academic partners. The stakeholders perceive the CoERI as a window of opportunity to formalise collaboration (Bennich-Björkman 1997). Enjoying a stamp of excellence alongside the activities and aims of innovation seemed to be an important issue in contributing to identity regulation and 'finding a home'. Even though the two logics overlap, they are subjects of constant negotiation and thus not free of incompatibilities. Property rights, openness and other issues are central topics of debate, but the research units have moved towards taking innovation for granted (Colyvas and Powell 2006).

Table 5 Four identity categories

Degree of compatibility between the logics

\begin{tabular}{|c|c|c|c|}
\hline \multirow{3}{*}{$\begin{array}{l}\text { Degree of } \\
\text { centrality } \\
\text { between } \\
\text { the logics }\end{array}$} & & High & Low \\
\hline & High & $\begin{array}{l}\text { The approved innovator } \\
\text { Legitimating innovation } \\
\text { logics through long-term } \\
\text { funding }\end{array}$ & $\begin{array}{l}\text { Torn in two directions } \\
\text { A clash of logics in } \\
\text { practice and perceptions }\end{array}$ \\
\hline & Low & $\begin{array}{l}\text { The autonomous agent } \\
\text { Tension free 'branded as } \\
\text { excellent' }\end{array}$ & $\begin{array}{l}\text { The traditionalist } \\
\text { One scale of excellence } \\
\text { and basic research }\end{array}$ \\
\hline
\end{tabular}




\section{Torn in two directions}

This researcher is affiliated with a CoERI but experiences low degree of compatibility between the logics. The centres are often based on unripe relations between the involved firms and academic researchers, and roles and activities are not well elaborated and integrated. Furthermore, our interviews indicated that the informants represented emerging fields associated with applied research striving for academic recognition. These conditions contributed to difficulties in establishing close collaboration practices and in developing good and uniting research questions, which made it hard to involve all partners.

Researchers that distanced themselves from the innovation logics emphasised the 'basicness' of their research and were seemingly not actively involved in the centre's innovation activities. Researchers adhering to the innovation logics claimed that their peers were negatively tuned to the research in the centre because of the innovation component and its perceived applied nature. For these researchers, the financing scheme contributed to making the incompatibilities between the logics even more explicit.

\section{The autonomous agent}

This researcher is typically affiliated with a $\mathrm{CoE}$ and perceives a high degree of compatibility between the two logics. The centre or the researcher has close ties to non-academic actors, and an identity integrating both logics is relatively unproblematic for researchers affiliated with a CoE. They enjoy the stamp of being 'excellent' in the wider scientific community and can pursue many different opportunities without losing the excellence brand. The researchers experience few incompatibilities in their quest for pursuing practices and goals associated with the institutional logics of innovation. There is therefore no need for identity regulation or negotiation.

\section{The traditionalist}

Affiliated with a $\mathrm{CoE}$, this researcher renounces the innovation logic and adheres to the logics of excellence, resembling the characteristics of Atkinson-Grosjean's (2006) 'settler' label. The emphasis is on the basic character of the research and its freedom from external constraints and influences, despite the fact that the centre may have external partners. Boundaries between the logics are well-defined with few overlaps. In these centres, the innovation logic has a low degree of centrality. Researchers work in a rather tension-free environment, at least in the centres which provide them with a shelter where their type of preferred research is the overarching goal.

These four identities indicate that the funding schemes affect researchers' identity and practices in different ways. The overarching pronounced goals of the centre (excellence and/or innovation) indicate whether one or both logics are central, but the extent to which they are compatible depends upon many other contextual factors. It seems like the synergies between research excellence and innovation, emphasised by researchers on innovation and the interaction between university and industry (Geuna and Nesta 2006; Salter and Martin 2001) excel in CoEs that have collaboration with industry/society. These researchers do not need to adjust their identities-the collaboration is based on the researchers' intrinsic motivation (Perkmann et al. 2011). This is also evident in CoERIs based on prior collaboration, where the funding mechanisms provide a 'home' with high degree of centrality and compatibility between the logics. In 
centres characterised by weak ties between the collaborating partners, the centrality of the logics (CoERIs high, CoEs low) in itself may lead to challenges of compatibility. Researchers in these centres distance themselves from the logic of innovation, resembling the identity conflict observed by Atkinson-Grosjean (2006) and Gulbrandsen (2005).

The funding schemes also affected researchers differently in Norway and Sweden. Researchers who saw the logics as highly compatible were primarily affiliated with Norwegian centres. This could be explained by the funding system; Swedish researchers depend more than Norwegian university researchers on external funding, and the characteristic of the funding agency (applied/industry related, basic research) and valuation of the grant seem to contribute to increased incompatibility between the logics. The tension-filled dynamics between the two logics in Swedish centres might be independent of the CoE or the CoERI, but the interviews indicated that the goals of the CoERI scheme made incompatibilities between logics more explicit. We find little evidence that the divergence in intellectual property legislation can explain these country differences. In general, the informants did not view the legislation as important, highlighting the continuity of practices (in Norway) from before the removal of the teacher exemption clause or how there are numerous ways to negotiate collaboration agreements that bypass the formal system (both countries).

\section{Conclusion}

Our research question in this paper is how and to what extent funding schemes with the goal of excellence and/or innovation affect researchers' identity and practices, pointing at a greater issue about how new funding mechanisms may act as agents of change in triple helix type relationships. The analysis is based on 33 in-depth interviews in 8 centres from 2 countries and different academic disciplines.

Previous research on the impact of governance and funding instruments on university researchers' identity and roles has emphasised the liminality and tensions for researchers occupying boundary spanning positions or hybrid roles between academia and commerce (Atkinson-Grosjean 2006; Owen-Smith and Powell 2002). By applying the institutional logics of excellence and innovation as the analytical framework, our results indicate that funding instruments-including whether they explicitly contain both logics in their goal formulation-evoke different identities that can be related to overlap and tensions between the two logics.

Centres of Excellence (CoEs; research-oriented only) are units with two main types of research identities. The 'traditionalists' are basic research-oriented academics working in a centre whose goals harmonise with the excellence logic and partly denounce the innovation logic which also has a low centrality in the centres. Contrarily, 'the autonomous researchers' are often engaged in other activities than basic research, having the freedom to do so without risk to their image as excellent because the logics are compatible, but the excellence logic has higher centrality.

Centres of Excellence in Research and Innovation (CoERIs; incorporating goals of innovation and excellence) involve two other identities. 'The approved innovators' are researchers with innovation/technology transfer experience affiliated with a centre set up to support these activities. Here, the logics have a high degree of compatibility and 
centrality, and the centre represents a formal legitimation of the researchers' activities and identity. Finally, the ones 'Torn in two directions' are found in CoERIs where the relations between firms and academics are undeveloped, and although both logics are central there seem to be a low degree of compatibility between them which causes several tensions for the individual researcher.

Overall, the funding mechanisms seem to have rather conservative effects. For example, if technology transfer activities exist prior to the centre establishment, they continue regardless of the goals of the centre. These patterns may partly be explained by the disciplinary context. Our study indicates that CoERIs may not work appropriately in situations where the academic discipline is not well established or when the relations between the discipline's researchers and external partners are immature. Moreover, national characteristics such as research funding systems also seem to moderate the effect of funding mechanisms on individual researcher's practices. The interviews indicate that when the centres have low funding or the funding competition is very high, especially the CoERIs may have little effects on practice because the individuals will also strive to adapt to the goals of other sorts of funding and support.

Our main contribution has been to point out that the effects of the long-term funding of centre instruments must be understood in a wider context including disciplinary characteristics and the overall funding system. Demands of the centre funding itself do matter, such as the required number of partners and evaluation criteria, but they play out in a larger context. Later studies may want to look more closely at factors like characteristics of the academic organisation. The eight centres in our study are located at two traditional and old universities, which mean that centres' agency may play out differently in other institutional settings. It would also be useful to get in-depth and longitudinal studies of centres in emerging fields to investigate whether centres may be a tool for new discipline formation. Studies of centre support and their co-effects with other funding mechanisms would also be interesting.

For policymakers, it should be noted that centre schemes seem to have fairly conserving effects at the individual level (they may have other effects on universities, though). These instruments are therefore not particularly suited to changing individual behaviour but appropriate for those who already view the two logics as compatible. Although some CoERIs are effective, especially for those who are already engaged in a combination of research and innovation and gain legitimacy through the centre, this is clearly not the right solution in all cases. When the academic discipline is poorly established or when the industry relations are very weak, other ways of improving relations or raising the quality of the research may need to be found.

\section{Endnotes}

${ }^{1}$ They are called VinnExcellence in Sweden and SFI in Norway, the centres are also known as 'Competence centres'

${ }^{2}$ They are called Linneaus Grant in Sweden and SFF in Norway.

\section{Additional file}


Abbreviations

CoE: Centres of excellence; CoERI: Centres of Excellence in Research and Innovation

\section{Acknowledgements}

We are grateful for the constructive comments of two anonymous reviewers

\section{Funding}

The project was primarily funded by the University of Oslo and had added support by the Research Council of Norway, grant 256223

\section{Availability of data and materials}

Information about the centre schemes can be found on the websites of the Research Council of Norway, the Swedish Research Council and Vinnova. The interview material cannot be shared due to privacy protection.

\section{Authors' contributions}

The first author was responsible for the design and interviews. Both authors have contributed to theory and analysis of the results. Both authors read and approved the final manuscript.

\section{Competing interests}

The authors declare that they have no competing interests.

\section{Publisher's Note}

Springer Nature remains neutral with regard to jurisdictional claims in published maps and institutional affiliations.

\section{Author details}

${ }^{1}$ Nordic Institute for Studies in Innovation, Research and Education (NIFU), Oslo, Norway. ${ }^{2}$ TIK Centre for Technology, Innovation and Culture, University of Oslo, Oslo, Norway.

Received: 21 September 2018 Accepted: 6 November 2018

\section{Published online: 20 December 2018}

\section{References}

Alvesson M, Ashcraft LK, Thomas R (2008) Identity matters: reflections on the construction of identity scholarship in organization studies. Organization 15:5-28

Atkinson-Grosjean J (2006) Public science; private interests: cultures and commerce in Canada's networks of centres of excellence. University of Toronto Press, Toronto

Bennich-Björkman L (1997) Organising innovative research, the inner life of university departments. Pergamon, Amsterdam Besharov ML, Smith WK (2014) Multiple institutional logics in organizations: explaining their varied nature and implications. Acad Manag Rev 39(3):364-381

Boardman C, Bozeman B (2007) Role strain in university research centres. J High Educ 78:430-463

Boardman C, Gray D (2010) The new science and engineering management: cooperative research centers as government policies, industry strategies, and organizations. J Technol Transf 35(5):445-459

Borlaug SB, Jacob M (2013) Who commercialises research at Swedish universities and why? Prometheus 31(2):139-152

Calvert J (2004) The idea of "basic research" in language and practice. Minerva 42:251-268

Colyvas JA, Powell WW (2006) Roads to institutionalization: the remaking of the boundaries between the public and private science. Res Organ Behav 27:305-353

Dooris MJ, Fairweather JS (1992) The organization of academic research: faculty behaviour and perceptions. Association for the Study of Higher Education, East Lansing

Eisenhardt KM (1989) Building theories from case study research. Acad Manag Rev 14:532-550

Etzkowitz H (1998) The norms of entrepreneurial science: cognitive effects of the new university-industry linkages. Res Policy 27(8):823-833

Etzkowitz H, Kemelgor C (1998) The role of research centres in the collectivisation of academic science. Minerva 36(3):271-288

Etzkowitz H, Leydesdorff $L$ (2000) The dynamics of innovation: from national systems and 'mode 2 ' to a triple helix of university-industry-government relations. Res Policy 29:109-123

Etzkowitz H, Peters LS (1991) Profiting from knowledge: organisational innovations and the evolution of academic norms. Minerva 29:133-166

Friedland R, Alford RR (1991) Bringing society back in: symbols, practices, and institutional contradictions. In: Powell WW, DiMaggio PJ (eds) The new institutionalism in organizational analysis. University of Chicago Press, Chicago, pp 232-266 Geuna A, Muscio A (2009) The governance of university knowledge transfer: a critical review of the literature. Minerva 47:93-114 Geuna A, Nesta L (2006) University patenting and its effects on academic research: the emerging European evidence. Res Policy 35:790-807

Gläser J, Laudel G (2016) Governing science: how science policy shapes research content. Eur J Soc 57(1):117-168

Glynn MA (2008) Beyond constraint: how institutions enable identities. In: Greenwood R, Oliver C, Sahlin K, Suddaby R (eds) The SAGE handbook of organizational institutionalism. Sage, London, pp 413-430

Greenwwod R, Raynard M, Kodeih FM, Micelotta E, Lounsberry M (2011) Institutional complexity and organizational responses. Acad Manag Ann 5:317-371

Gulbrandsen M (2005) 'But Peter's in it for the money' — the liminality of entrepreneurial scientists. Vest 18:49-75

Gulbrandsen M, Kyvik S (2010) Are the concepts basic research, applied research and experimental development still useful? An empirical investigation among Norwegian academics. Sci Public Policy 37:343-353

Gulbrandsen M, Smeby JC (2005) Industry funding and university professors' research performance. Res Policy 34:932-950 
Heinze T, Shapira P, Rogers JD, Senker JM (2009) Organizational and institutional influences on creativity in scientific research. Res Policy 38:610-623

Hessels LK, van Lente H (2011) Practical applications as a source of credibility: a comparison of three fields of Dutch academic chemistry. Minerva 49:215-240

Hollingsworth JR (2008) Scientific discoveries: an institutionalist and path-dependent perspective. In: Hannaway C (ed) Biomedicine in the twentieth century: practices, policies, and politics. IOS Press, Amsterdam, pp 317-353

Jain S, George G, Maltarich M (2009) Academics or entrepreneurs? Investigating role identity modification of university scientists involved in commercialization activity. Res Policy 38:922-935

Kraatz MS, Block ES (2008) Organizational implications of institutional pluralism. In: Greenwood R, Oliver C, Sahlin K, Suddaby R (eds) The SAGE handbook of organizational institutionalism. Sage, London, pp 243-275

Lamont M (2009) How professors think. In: Inside the curious world of academic judgment. Harvard University Press, Cambridge

Leisyte L, Enders J (2011) The strategic responses of English and Dutch university life scientists to the changes in their institutional environments. In Reform of higher education in Europe (pp. 143-157). SensePublishers

Leisyte L, Hosch-Dayican B (2016) Boundary crossing and maintenance among UK and Dutch bioscientists towards hybrid identities of academic entrepreneurs. Organizing academic work in higher education: teaching, learning and Identities, vol 223

Lok J (2010) Institutional logics as identity projects. Acad Manag J 53:1305-1335

Luukkonen T, Nedeva M, Barré R (2006) Understanding the dynamics of networks of excellence. Sci Public Policy 33(4):239-252

Merton R (1973) The sociology of science: theoretical and empirical investigations. University of Chicago Press, Chicago

Meyer RE, Hammerschmid G (2006) Changing institutional logics and executive identities: a managerial challenge to public administration in Austria. Am Behav Sci 49:1000-1014

Nedeva M. et al. (2012) Understanding and assessing the impact and outcomes of the ERC and its funding schemes (EURECIA). Final synthesis report. European Research Council. https:/erc.europa.eu/sites/default/files/document/file/ eurecia_final_synthesis_report.pdf

Orr D, Jaeger M, Wespel J (2011) New forms of incentive funding for public research: a conceptpaper on research excellence initiatives. OECD, Paris

Owen-Smith J, Powell WW (2002) Standing on shifting terrain: faculty responses to the transformation of knowledge and its uses in the life sciences. Sci Stud 15:3-28

Perkmann M, King Z, Pavelin S (2011) Engaging excellence? Effects of faculty quality on university engagement with industry. Res Policy 40:539-552

Powell WW, Colyvas JA (2008) Microfoundations of institutional theory. In: Greenwood R, Oliver C, Sahlin K, Suddaby R (eds) The SAGE handbook of organizational institutionalism. Sage, London, pp 243-275

Rao H, Monin P, Durand R (2003) Institutional change in toque Ville: nouvelle cuisine as an identity movement in French gastronomy. Am J Sociol 108:795-843

Salter AJ, Martin BR (2001) The economic benefits of publicly funded basic research: a critical review. Res Policy 30:509-532

Slaughter S, Rhoades G (2004) Academic Capitalism and the New Economy. Markets, State, and Higher Education. The John Hopkins University Press, Baltimore

Thornton PH, Ocasio W, Lounsbury M (2012) The institutional logics perspective: a new approach to culture, structure, and process. New York: Oxford University Press

Whitley R (2000) The intellectual and social Organization of the Sciences, 2nd edn. Clarendon Press, Oxford

Whitley R (2003) Competition and pluralism in the public sciences: the impact of institutional frameworks on the organisation of academic science. Res Policy 32(6):1015-1029

Youtie J, Shapira P (2008) Building an innovation hub: a case study of the transformation of university roles in regional technological and economic development. Res Policy 37:1188-1204

\section{Submit your manuscript to a SpringerOpen ${ }^{\circ}$ journal and benefit from:}

- Convenient online submission

Rigorous peer review

- Open access: articles freely available online

- High visibility within the field

- Retaining the copyright to your article

Submit your next manuscript at $\boldsymbol{\nabla}$ springeropen.com 